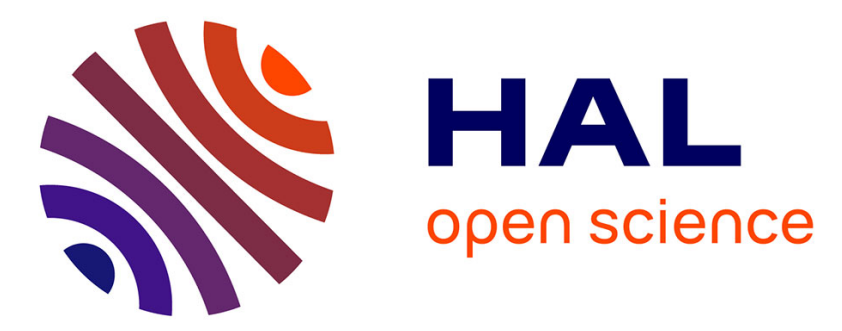

\title{
Haloalkane hydrolysis by Rhodococcus erythropolis cells: Comparison of conventional aqueous phase dehalogenation and nonconventional gas phase dehalogenation
}

Benjamin Erable, Isabelle Goubet, Sylvain Lamare, Marie Dominique Legoy, Thierry Maugard

\section{To cite this version:}

Benjamin Erable, Isabelle Goubet, Sylvain Lamare, Marie Dominique Legoy, Thierry Maugard. Haloalkane hydrolysis by Rhodococcus erythropolis cells: Comparison of conventional aqueous phase dehalogenation and nonconventional gas phase dehalogenation. Biotechnology and Bioengineering, 2004, vol. 86, pp. 47-54. 10.1002/bit.20035 . hal-00786190

\section{HAL Id: hal-00786190 https://hal.science/hal-00786190}

Submitted on 8 Feb 2013

HAL is a multi-disciplinary open access archive for the deposit and dissemination of scientific research documents, whether they are published or not. The documents may come from teaching and research institutions in France or abroad, or from public or private research centers.
L'archive ouverte pluridisciplinaire $\mathbf{H A L}$, est destinée au dépôt et à la diffusion de documents scientifiques de niveau recherche, publiés ou non, émanant des établissements d'enseignement et de recherche français ou étrangers, des laboratoires publics ou privés. 


\title{
Haloalkane Hydrolysis by Rhodococcus erythropolis Cells: Comparison of Conventional Aqueous Phase Dehalogenation and Nonconventional Gas Phase Dehalogenation
}

\author{
Benjamin Erable, Isabelle Goubet, Sylvain Lamare, Marie Dominique Legoy, \\ Thierry Maugard \\ Laboratoire de Génie Protéique et Cellulaire, EA3169, Bâtiment Marie Curie, \\ Université de La Rochelle, Avenue Michel Crépeau, 17042 La Rochelle cedex 1, \\ France; fax: (33) 5464582 65; e-mail: tmaugard@univ-Ir.fr \\ origoubet@univ-Ir.fr
}

\begin{abstract}
Biofiltration of air polluted by volatile organic compounds is now recognized by the industrial and research communities as an effective and viable alternative to standard environmental technologies. Whereas many studies have focused on solid/liquid/gas biofilters, there have been fewer reports on waste air treatment using other biological processes, especially in a solid/gas biofilter. In this study, a comparison was made of the hydrolysis of halogenated compounds (such as 1-chlorobutane) by lyophilized Rhodococcus erythropolis cells in a novel solid/ gas biofilter and in the aqueous phase. We first determined the culture conditions for the production of $R$. erythropolis cells with a strong dehalogenase activity. Four different media were studied and the amount of 1-chlorobutane was optimized. Next, we report the possibility to use $R$. erythropolis cells in a solid/gas biofilter in order to transform halogenated compounds in corresponding alcohols. The effect of experimental parameters (total flow into the biofilter, thermodynamic activity of the substrates, temperature, carbon chain length of halogenated substrates) on the activity and stability of lyophilized cells in the gas phase was determined. A critical water thermodynamic activity $\left(a_{w}\right)$ of 0.4 is necessary for the enzyme to become active and optimal dehalogenase activity for the lyophilized cells is obtained for an $a_{w}$ of 0.9. A temperature of reaction of $40^{\circ} \mathrm{C}$ represents the best compromise between stability and activity. Activation energy of the reaction was determined and found equal to $59.5 \mathrm{KJ} / \mathrm{mol}$. The $\mathrm{pH}$ effect on the dehalogenase activity of $R$. erythropolis cells was also studied in the gas phase and in the aqueous phase. It was observed that $\mathrm{pH} 9.0$ provided the best activity in both systems. We observed that in the aqueous phase $R$. erythropolis cells were less sensitive to the variation in $\mathrm{pH}$ than $R$. erythropolis cells in the gas phase. Finally, the addition of volatile Lewis base (triethylamine) in the gaseous phase and the action of the lysozyme in order to permeabilize the cells was found to be highly
\end{abstract}

Correspondence to: Isabelle Goubet or Thierry Maugard beneficial to the effectiveness of the biofilter. (C) 2004 Wiley Periodicals, Inc.

Keywords: waste air treatment; bioremediation; solid/ gas biofilter; haloalkane dehalogenase; Rhodococcus erythropolis

\section{INTRODUCTION}

Biological waste air treatment is an emerging technology which is becoming more popular with industries facing increasingly stringent environmental regulation (US EPA, 1990). This technique offers a cost-effective and environmentally friendly alternative to conventional air pollutant control technologies such as catalytic oxidation or adsorption onto activated carbon (Menig and Krill, 1997; Cox and Deshusses, 1998). Gaseous effluent treatment processes were reviewed and compared by Jorio and Heitz (1999), who showed that the cost of biological treatment was among the lowest. Indeed, biological waste air treatment is achieved at ambient temperatures and does not involve high running costs. Moreover, it does not generate secondary pollutants, such as nitrogen oxides (Jorio and Heitz, 1999). Generally, pollutants are converted to carbon dioxide, water, mineral salts, and biomass.

Although there have been many articles dealing with biofilters (solid/liquid/gas bioreactor), there have been fewer reports on waste air treatment by other biological processes, especially on the direct treatment of gaseous effluents in a solid/gas biofilter. However, this kind of process could be of interest in the transformation of volatile organic compounds (VOCs) (Maugard et al., 2001; Goubet et al., 2002). Indeed, solid/gas catalysis does not require the preliminary solubilization of compounds since substrates are directly treated in the gas phase. This could be of great interest in the treatment of VOCs, which often have a low solubility in water and are relatively volatile. With solid/gas catalysis, the viability of 
the biofilter is not limited by biomass development since the dehydrated catalyst does not grow. In addition, it does not need to be fed with nutrients and the bioreactor's efficiency does not depend on cell viability. Moreover, mass transfers in such systems are more efficient than in a conventional solid/liquid/gas system (Lamare and Legoy, 1993; Lamare et al., 2001).

Among the VOCs, halogenated compounds form one of the most important groups of industrially produced chemicals. Many of them have been designated as priority pollutants by the US EPA because of their recalcitrance, toxicity, carcinogenicity, and potential teratogenicity (Keith and Teillard, 1979; Belkin, 1992). Biodegradation of short chain chloroalkanes in a solid/gas biofilter by the haloalkane dehalogenase of Rhodococcus erythropolis has recently been reported (Dravis et al., 2000). This work showed that haloalkane dehalogenase can hydrolyse chlorinated substrates into the corresponding alcohols and $\mathrm{HCl}$ in the gas phase. Since enzyme purification would increase the cost of a gaseous effluent treatment process, it was decided to use dehydrated cells as catalyst. Moreover, if no cofactor is needed for successive reactions, the use of whole-dehydrated cells could favor the catalysis of several steps of the conversion, which is particularly valuable for bioremediation. Recently, it has been shown that lyophilized Saccharomyces cerevisiae cells (baker's yeast) can be used as a catalyst for the transformation of alcohols and aldehydes (Maugard et al., 2001; Goubet et al., 2002).

The purpose of this study was to investigate if lyophilized $R$. erythropolis cells could be used for the dehalogenation of gaseous substrates. We focused on the effect of culture and dehydration conditions of the microorganism, as well as on the effect of operating conditions on the conversion efficiency of a solid/gas biofilter. We compared conventional aqueous phase dehalogenation with nonconventional gas phase dehalogenation.

\section{MATERIALS AND METHODS}

\section{Microorganisms, Culture Conditions, and Chemicals}

Rhodococcus erythropolis NCIMB 13064, was obtained from the National Collection of Industrial and Marine Bacteria (Aberdeen, Scotland). The organism was grown in 1-L Erlenmeyer flasks sealed with Teflon-lined screw caps containing $200 \mathrm{~mL}$ of medium at pH 7.0. All substrates were purchased from Sigma Chemical (St. Louis, MO) except tryptone and yeast extract, which were obtained from Fluka (Ronkonkoma, NY). Deionized water was obtained via a Milli-Q system (Millipore, France).

\section{Culture Conditions}

Four different media were tested: 2YT, M9, and two mineral media described by Curragh et al. (1994) and Sorkhoh et al. (1991), respectively. The 2YT medium had the following composition (in $\mathrm{g} / \mathrm{L}$ ): 16.0 tryptone, 10.0 yeast extract, and
5.0 NaCl. The M9 medium had the following composition $(\mathrm{g} / \mathrm{L})$ : $6.0 \mathrm{Na}_{2} \mathrm{HPO}_{4} \cdot 2 \mathrm{H}_{2} \mathrm{O} 3.0 \mathrm{KH}_{2} \mathrm{PO}_{4}, 1.0 \mathrm{NH}_{4} \mathrm{Cl}$, $0.5 \mathrm{NaCl}, 0.05 \mathrm{MgSO}_{4} \cdot \mathrm{H}_{2} \mathrm{O}, 0.0002$ thiamine $/ \mathrm{HCl}$, and $0.004 \mathrm{CaCl}_{2} \cdot \mathrm{H}_{2} \mathrm{O}$. The mineral medium described by Curragh et al. (1994) had the following composition (g/L): $1.6 \mathrm{NaH}_{2} \mathrm{PO}_{4} \cdot 2 \mathrm{H}_{2} \mathrm{O}, 1.4 \mathrm{Na}_{2} \mathrm{HPO}_{4}, 0.5\left(\mathrm{NH}_{4}\right)_{2} \mathrm{SO}_{4}$, $0.2 \mathrm{MgSO}_{4} \cdot 7 \mathrm{H}_{2} \mathrm{O}$, and $0.5 \mathrm{~K}_{2} \mathrm{SO}_{4}$; the medium was supplemented with a trace element solution $(10 \mathrm{~mL} / \mathrm{L})$ containing: 12.0 NaEDTA $2 \mathrm{H}_{2} \mathrm{O}, 2.0 \quad \mathrm{FeSO}_{4} \cdot 7 \mathrm{H}_{2} \mathrm{O}$, $1.0 \mathrm{CaCl}_{2}, 0.4 \mathrm{ZnSO}_{4} \cdot 7 \mathrm{H}_{2} \mathrm{O}, 0.4 \mathrm{MnSO}_{4} \cdot 4 \mathrm{H}_{2} \mathrm{O}$, and $0.1 \mathrm{CuSO}_{4} \cdot 5 \mathrm{H}_{2} \mathrm{O}$. The $\mathrm{pH}$ of the medium was adjusted to 7.0 with $\mathrm{HCl}$. The mineral medium described by Sorkhoh et al. (1991) had the following composition (g/L): $0.85 \mathrm{NaNO}_{3}, 0.56 \mathrm{KH}_{2} \mathrm{PO}_{4}, 0.86 \mathrm{Na}_{2} \mathrm{HPO}_{4}, 0.17 \mathrm{~K}_{2} \mathrm{SO}_{4}$, $0.37 \mathrm{MgSO}_{4} \cdot 7 \mathrm{H}_{2} \mathrm{O}, 0.007 \mathrm{CaCl}_{2} \cdot 2 \mathrm{H}_{2} \mathrm{O}$, and $2.5 \mathrm{ml}$ of a trace element solution consisting of $(\mathrm{g} / \mathrm{L}): 2.32 \mathrm{ZnSO}_{4} \cdot 7 \mathrm{H}_{2} \mathrm{O}$, $1.78 \mathrm{MnSO}_{4} \cdot 4 \mathrm{H}_{2} \mathrm{O}, 0.56 \mathrm{H}_{3} \mathrm{BO}_{3}, 1.0 \mathrm{CuSO}_{4} \cdot 5 \mathrm{H}_{2} \mathrm{O}$, $0.39 \mathrm{NaMoO}_{4} \cdot 2 \mathrm{H}_{2} \mathrm{O}, 0.42 \mathrm{CoCl}_{2} \cdot 6 \mathrm{H}_{2} \mathrm{O}, 0.66 \mathrm{KI}, 0.1$ EDTA, $0.4 \mathrm{FeSO}_{4} \cdot 7 \mathrm{H}_{2} \mathrm{O}$, and $0.0004 \mathrm{NiCl}_{2} \cdot 6 \mathrm{H}_{2} \mathrm{O}$. The $\mathrm{pH}$ of each medium was adjusted to $\mathrm{pH} 7.0$ with $\mathrm{HCl}$. The media were sterilized by autoclaving for $15 \mathrm{~min}$ at $121^{\circ} \mathrm{C}$. After cooling, 100-200 $\mu \mathrm{L}(0.96-1.92 \mathrm{mmol})$ of filter-sterilized 1-chlorobutane was added once or twice to each screw capsealed flask. Cultures were incubated at $28^{\circ} \mathrm{C}$ on an orbital shaker $(160 \mathrm{rpm})$. Growth of the organism was monitored by measuring the Absorbance at $690 \mathrm{~nm}\left(\mathrm{~A}_{690 \mathrm{~nm}}\right)$.

\section{Preparation of Cells}

Cells grown for $24-48 \mathrm{~h}$ were harvested by centrifugation at $7,000 \mathrm{rpm}$ for $10 \mathrm{~min}$. The cell paste was washed with $50 \mathrm{mM}$ Tris/HCl buffer at $\mathrm{pH} 6.2,7.0,7.5,8.0,8.5$, or 9.0 and resuspended in $50 \mathrm{mM}$ Tris/ $\mathrm{HCl}$ buffer at the same $\mathrm{pH}$. To perform degradation tests the volume of buffer used for suspension of cells was half of the volume used for culture. The volume of buffer used to suspend cells before freezedrying was one-tenth of the volume used for culture. One part was used for substrate conversion tests in the aqueous phase and the rest was lyophilized prior to use in the solid/ gas biofilter.

\section{Effect of Cell Permeabilization on Dehalogenase Activity}

Cells grown for $48 \mathrm{~h}$ on Sorkhoh's mineral medium supplemented twice with $100 \mu \mathrm{L}$ of 1-chlorobutane were permeabilized by treatment with lysozyme. Then $200 \mathrm{mg}$ of lysozyme were added to $600 \mathrm{mg}$ of harvested cells washed and resuspended in $30 \mathrm{~mL}$ of Tris/ $\mathrm{HCl}$ buffer $(50 \mathrm{mM}$, $\mathrm{pH}$ 9.0). After a 15 -min incubation at $22^{\circ} \mathrm{C}$, the preparation was frozen at $-20^{\circ} \mathrm{C}$ and lyophilized. Lysozyme was obtained from Sigma Chemical Co.

\section{Enzyme Assay for Dehalogenation in the Aqueous Phase}

Tests were performed with $10 \mathrm{~mL}$ of cell suspension (in Tris/HCl buffer) in Teflon-lined screw cap-sealed tubes to 
which $7 \mu \mathrm{L}(67 \mu \mathrm{mol})$ of substrate was added. The reaction was stopped by addition of $2 \mathrm{~mL}$ of dichloromethane. Concentrations of the remaining substrate and corresponding alcohol in the extract were monitored by gas chromatography analysis using 1-hexanol (or 1-butanol) as an internal standard and the same analytical conditions as for the analysis of the gas phase leaving the reactor. Controls containing buffer and substrate alone were used to measure any abiotic dehalogenation and additional controls containing cells grown on 2YT medium without 1-chlorobutane (also lacking the dehalogenase) were used to measure the amount of 1-chlorobutane adsorbed on cells.

\section{Enzyme Assay for Dehalogenation in the Solid/Gas Biofilter}

The solid/gas biofilter used in this study has been described previously by Lamare and Legoy (1995). It consists of a $9 \mathrm{~cm}$ long glass tube in which the lyophilized $R$. erythropolis cells are packed between two layers of glass wool. Nitrogen was used as a carrier gas. It first passed through the substrate saturation flasks and a continuous flow through the biofilter ensured a reaction with the lyophilized $R$. erythropolis cells. The gas leaving the biofilter was injected into a gas chromatograph for analysis. Acquisition and control of the operating parameters (thermodynamic activity of substrates and of water, temperature, and pressure) were monitored online using a compatible IBM computer.

The key parameters considered for the solid/gas biocatalysis are the "availability" of the different chemical species in the gas phase for the cell. The thermodynamic parameter corresponding to each "availability" is the activity of each compound. For each compound present in the gas phase, determination of its thermodynamic activity requires knowledge of its partial pressure in the gaseous phase to be transformed and knowledge of the vapor pressure curve as a function of temperature.

The thermodynamic activity of each compound $(\mathrm{X})$ in the reactor was calculated as follows:

$$
a_{x}=\frac{P p_{x}}{P p_{x}^{S a t}}
$$

with $P p_{x}$ : partial pressure of compound X (atm) in the gas entering the biofilter $P p_{x}^{S a t}$ : saturation vapor pressure of pure compound $\mathrm{X}$ (atm) at the operating temperature.

A typical experiment was run at $40^{\circ} \mathrm{C}$ with $100 \mathrm{mg}$ of lyophilized cells. The total flow through the biofilter was $500 \mu \mathrm{mol} / \mathrm{min}$. The 1 -chlorobutane thermodynamic activity $\left(a_{\text {ClBut }}\right)$ was set at 0.06 (corresponding to $8.1 \mu \mathrm{mol} / \mathrm{min}$ of 1-chlorobutane at $40^{\circ} \mathrm{C}$ ) and the water thermodynamic activity $\left(a_{\mathrm{w}}\right)$ at 0.8 (corresponding to $30.0 \mu \mathrm{mol} / \mathrm{min}$ of water at $\left.40^{\circ} \mathrm{C}\right)$.

With these experimental conditions, less than $5 \%$ of the substrates were converted; it could thus be assumed that the initial rates (expressed in $\mu \mathrm{mol}$ of 1-butanol produced per minute and per $g$ of cell) were measured. The vapor phase leaving the biofilter was sampled using a $250 \mu \mathrm{L}$ loop on a six-way valve (Valco, Houston, TX) maintained at $190^{\circ} \mathrm{C}$. Samples were automatically injected into the split injector of a gas chromatograph.

\section{Chromatographic Analysis}

Analysis were performed on a gas chromatograph (Hewlett Packard, Corvallis, OR, model 5890 A), equipped with a flame ionization detector (FID). The column used was an OV 1701 fused silica capillary column $(25 \mathrm{~m} \times 0.25 \mathrm{~mm}$ i.d. $\times$ $0.25 \mu \mathrm{m}$ film thickness; Chrompack, France). The split ratio was $43.2 / 2.7$. The injector was kept at $200^{\circ} \mathrm{C}$, and the detector was kept at $250^{\circ} \mathrm{C}$. The column temperature was held at $40^{\circ} \mathrm{C}$ for $2.5 \mathrm{~min}$, then programmed to increase at $15^{\circ} \mathrm{C} / \mathrm{min}$ to $110^{\circ} \mathrm{C}$ and kept $1 \mathrm{~min}$ at this temperature. Nitrogen was used as carrier gas and the flow rate in the column was $2.7 \mathrm{~mL} / \mathrm{min}$. Hydrogen and air were supplied to the FID at 38 and $398 \mathrm{~mL} / \mathrm{min}$, respectively. Quantitative data were obtained after integration on an HP 3396A integrator. An internal standard was used for analysis of the liquid phases and an external standard method was used for analysis of the gaseous phase leaving the reactor.

\section{RESULTS AND DISCUSSION}

\section{Effect of the Medium on the Growth and Dehalogenase Activity of Rhodococcus erythropolis Cells}

Four media were first compared for the development of $R$. erythropolis and the expression of dehalogenase activity. Media assessed included one nutrient media (2YT) and three mineral media (the M9 and two media previously used for R. erythropolis culture [Sorkhoh et al., 1991; Curragh et al., 1994]). In all media, $0.5 \mu \mathrm{L}$ of 1 -chlorobutane per $\mathrm{mL}$ of medium was added. In the mineral media it was the sole source of carbon and energy. As shown in Table I, growth in 2YT was approximately twice that obtained with the other media, but the cells obtained had a weak dehalogenase

Table I. Growth and dehalogenase activity of $R$. erytropolis cells in different culture media (supplemented with 1-chlorobutane).

\begin{tabular}{lcc}
\hline \multicolumn{1}{c}{ Culture medium } & Growth $\left(\mathrm{A}_{690 \mathrm{~nm}}\right)$ & $\begin{array}{c}\text { Dehalogenase activity } \\
\left(\mu \mathrm{mol} / \mathrm{min} . \mathrm{A}_{690 \mathrm{~nm}}\right)\end{array}$ \\
\hline 2YT medium & 1.96 & 1.27 \\
M9 medium & 1.03 & 1.32 \\
Minimal salt medium $^{\mathrm{a}}$ & 0.95 & 1.52 \\
Minimal salt medium $^{\mathrm{b}}$ & 0.86 & 3.15 \\
\hline
\end{tabular}

Cells were grown for $24 \mathrm{~h}$ on 2 YT medium and for $48 \mathrm{~h}$ on the other media, at $28^{\circ} \mathrm{C}$ in $1-\mathrm{L}$ sealed flasks containing $200 \mathrm{~mL}$ of medium to which $100 \mu \mathrm{L}(0.96 \mathrm{mmol})$ of 1-chlorobutane was added. Cells were then harvested, washed twice with Tris/ $\mathrm{HCl}$ buffer $(50 \mathrm{mM}, \mathrm{pH} 9.0)$, and suspended in Tris/ $\mathrm{HCl}$ buffer $(50 \mathrm{mM}, \mathrm{pH} 9.0)$; 1-chlorobutane was added at a $700 \mu \mathrm{L} / \mathrm{L}$ concentration; dehalogenation was measured by GC analysis.

${ }^{a}$ Minimal salt medium described by Curragh et al. (1994).

${ }^{\mathrm{b}}$ Minimal salt medium described by Sorkhoh et al. (1991). 
activity. Conversely, cell production in Sorkhoh's medium was low but a significant dehalogenase activity was obtained. This medium was selected for further tests and for the production of a biocatalyst.

\section{Effect of the Amount of 1-Chlorobutane Added to the Culture}

In order to determine the optimal concentration of 1-chlorobutane for the growth of $R$. erythropolis cells, different concentrations of 1-chlorobutane in the medium were studied. Cells were grown for $48 \mathrm{~h}$ at $28^{\circ} \mathrm{C}$ in $1-\mathrm{L}$ Teflon-sealed flasks containing $200 \mathrm{~mL}$ of Sorkhoh's medium. The addition of $100 \mu \mathrm{L}$ of substrate once at the beginning of culture resulted in the production of cells with the highest specific activity (Table II). The best conditions were obtained with twice the addition of $100 \mu \mathrm{L}$ of substrate, which provided both strong growth $\left(\mathrm{A}_{690 \mathrm{~nm}}: 1.21\right)$ and a high specific activity, thus a high amount of catalytic activity. A very high concentration of 1-chlorobutane in the culture medium inhibited cell growth $\left(\mathrm{A}_{690 \mathrm{~nm}}: 0.26\right)$ and resulted in a low dehalogenase activity.

\section{Effect of the Total Flow of the Gas Phase Through the Biofilter}

After checking that the lyophilized preparations were still active when resuspended in the aqueous phase, we used lyophilized cells in a solid/gas biofilter. The biofilter was packed with $100 \mathrm{mg}$ of lyophilized cells and fed with $500 \mu \mathrm{mol} / \mathrm{min}$ of a gaseous phase at $40^{\circ} \mathrm{C}$ with an $a_{\mathrm{w}}$ fixed at 0.8 (corresponding to $30.0 \mu \mathrm{mol} / \mathrm{min}$ at $40^{\circ} \mathrm{C}$ ) and an $a_{\mathrm{ClBut}}$ fixed at 0.06 (corresponding to $8.1 \mu \mathrm{mol} / \mathrm{min}$ at $40^{\circ} \mathrm{C}$ ). The course of the reaction was followed by GC analysis. The decrease of 1-chlorobutane concentration was seen to be concomitant with the synthesis of 1-butanol. No other compound could be detected in the gas phase. In the absence of lyophilized cells in a solid/gas biofilter, product did not appear.

Table II. Effect of the amount of 1-chlorobutane added to the medium on growth and dehalogenase activity of $R$. erythropolis cells grown on $200 \mathrm{~mL}$ of Sorkhoh's minimal salt medium.

\begin{tabular}{ccc}
\hline $\begin{array}{l}\text { Amount of } \\
\text { 1-chlorobutane added }\end{array}$ & Growth $\mathrm{A}_{690 \mathrm{~nm}}$ & $\begin{array}{c}\text { Dehalogenase activity } \\
(\mu \mathrm{mol} / \mathrm{min} . \mathrm{A})\end{array}$ \\
\hline $100 \mu \mathrm{L}$ & 0.51 & 5.38 \\
$200 \mu \mathrm{L}$ & 1.41 & 3.02 \\
$400 \mu \mathrm{L}$ & 0.26 & 0.59 \\
$2 \times 10 \mu \mathrm{L}$ & 1.21 & 4.69 \\
$2 \times 200 \mu \mathrm{L}$ & 1.10 & 2.18 \\
\hline
\end{tabular}

Cells were grown for $48 \mathrm{~h}$ at $28^{\circ} \mathrm{C}$ in $1-\mathrm{L}$ sealed flasks containing $200 \mathrm{~mL}$ of medium to which 100,200 , or $400 \mu \mathrm{L}$ of 1-chlorobutane was added. When substrate was added twice, the second addition was made $24 \mathrm{~h}$ after the first. Cells were then harvested, washed twice with $\mathrm{Tris} / \mathrm{HCl}$ buffer (50 mM, pH 9.0), and suspended in Tris/ $\mathrm{HCl}$ buffer (50 mM, pH 9.0); 1-chlorobutane was added at a $700 \mu \mathrm{L} / \mathrm{L}$ concentration; dehalogenation was measured by GC analysis.
This clearly shows that 1 -chlorobutane can be directly converted to 1-butanol and $\mathrm{HCl}$ in the gas phase using lyophilized $R$. erythropolis cells, but it would seem that this alcohol is not metabolized further. This could be due either to the fact that the only enzyme active in the gas phase is the dehalogenase or to the fact that only small amounts of catalyst were used and that we were not able to detect traces of secondary products. A third hypothesis is that the enzymes involved in the conversion of 1-butanol require cofactors and that since only 1-chlorobutane was supplied as a substrate, these enzymes were unable to regenerate their cofactors and remain active for a sufficiently long period. Poelarends et al. (2000) proposed that 1-butanol is further converted in butanal by a dehydrogenase requiring a cofactor. If such an enzyme is involved in the conversion of 1-butanol by $R$. erythropolis cells, it is logical that no secondary products were detected in our experiment.

The maximal initial reaction rate of 1-butanol formation observed in the gas phase with a $500 \mu \mathrm{mol} / \mathrm{min}$ total flow was $2.9 \mu \mathrm{mol} / \mathrm{min} . \mathrm{g}$ of lyophilized cells. Dravis et al. (2000) observed 7 times lower rates of conversion in the gas phase with pure dehalogenase $(0.4 \mu \mathrm{mol} / \mathrm{min} . \mathrm{g}$ of lyophilized dehalogenase). This difference could be due to the fact that in our experiment $a_{\mathrm{ClBut}}$ was maintained at 0.06, whereas Dravis et al. (2000) used 1-chlorobutane saturated vapor (activity close to 1 ), which could inhibit the enzyme. Moreover, in our experiment the products were continuously flushed by nitrogen, whereas Dravis et al. used a static system.

The reaction rate was measured with three gaseous flows while maintaining the same water and substrate activities (Table III). When the total flow decreased, the initial rate of 1-butanol formation increased. When the total flow in the reactor was $750 \mu \mathrm{mol} / \mathrm{min}(11.7 \mu \mathrm{mol} / \mathrm{min}$ of 1 -chlorobutane) 1-chlorobutane was transformed into 1-butanol at a rate of $1.9 \mu \mathrm{mol} / \mathrm{min}$.g of cells, when the total flow was $500 \mu \mathrm{mol} / \mathrm{min}(8.1 \mu \mathrm{mol} / \mathrm{min}$ of 1 -chlorobutane $)$ the substrate was transformed with a rate of $2.9 \mu \mathrm{mol} / \mathrm{min} . \mathrm{g}$, and when the total flow was $250 \mu \mathrm{mol} / \mathrm{min}(43 \mu \mathrm{mol} / \mathrm{min}$ of 1-chlorobutane) the substrate was transformed at rate of $3.7 \mu \mathrm{mol} / \mathrm{min} . \mathrm{g}$. Decreasing the flow in the reactor from 750 to $250 \mu \mathrm{mol} / \mathrm{min}$ increased the conversion rate from $\sim 1.6 \%$ to $8.6 \%$ (with $100 \mathrm{mg}$ of dehydrated cell), which could be explained by the longer residence time in the bioreactor.

\section{Effect of $\mathrm{pH}$ on the Dehalogenase Activity of Rhodococcus erythropolis Cells}

In nonconventional media, as in aqueous media, enzyme activity is dependent on the enzyme ionization state. Enzyme activity is dependent on the last aqueous $\mathrm{pH}$ to which the enzyme is exposed prior to drying (" $\mathrm{pH}$ memory") (Zaks and Klibanov, 1985; Halling, 2000). It might also be expected that the $\mathrm{pH}$ of the buffer used for the suspension of cells prior to lyophilization would influence the solid catalyst activity. Consequently, we studied the effect of $\mathrm{pH}$ 
Table III. Effect of the total flow of gas phase through the reactor on the rate of 1-butanol formation by lyophilized cells of $R$. erythropolis.

\begin{tabular}{|c|c|c|c|c|}
\hline $\begin{array}{l}\text { Total flow } \\
(\mu \mathrm{mol} / \mathrm{min})\end{array}$ & $\begin{array}{c}\text { Flow of } \\
\text { 1-chlorobutane } \\
(\mu \mathrm{mol} / \mathrm{min} . \mathrm{g})\end{array}$ & $\begin{array}{l}\text { Residence } \\
\text { time (Sec) }\end{array}$ & $\begin{array}{c}\text { Rate of } \\
\text { production 1-butanol } \\
(\mu \mathrm{mol} / \mathrm{min} . \mathrm{g})\end{array}$ & $\begin{array}{l}\text { Conversion yield } \\
\text { with } 100 \mathrm{mg} \\
\text { of cell }(\%)\end{array}$ \\
\hline 250 & 4.3 & 10.9 & 3.7 & 8.6 \\
\hline 500 & 8.1 & 5.5 & 2.9 & 3.5 \\
\hline 750 & 11.7 & 3.6 & 1.9 & 1.6 \\
\hline
\end{tabular}

on the dehalogenase activity of lyophilized $R$. erythropolis cells. Cells grown for $48 \mathrm{~h}$ on Sorkhoh's mineral medium supplemented twice with $100 \mu \mathrm{L}$ of 1-chlorobutane were harvested, washed with $50 \mathrm{mM}$ Tris/ $\mathrm{HCl}$ buffer $(\mathrm{pH}$ 6.2, 7.0, 8.0, or 9.0), and resuspended in $\mathrm{Tris} / \mathrm{HCl}$ buffer at the same $\mathrm{pH}$.

In both the aqueous and the gas phases, and in the range of $\mathrm{pH}$ studied ( $\mathrm{pH}$ 6.2-9.0), an increase of cellular dehalogenase activity was observed. In both cases, for the range of $\mathrm{pH}$ studied, the maximal dehalogenase activity was observed at pH 9.0 (Fig. 1). Moreover, we observed that in the aqueous phase $R$. erythropolis cells were less sensitive to the variation in $\mathrm{pH}$ than $R$. erythropolis cells in the gas phase. Indeed, in the gas phase a reduction in $\mathrm{pH}$ of 0.5 from $\mathrm{pH} 9.0$ to 8.5 induced a drop of $50 \%$ in the dehalogenase activity, whereas in the aqueous phase this decrease was obtained with a reduction in $\mathrm{pH}$ of 1.5. In the absence of cells in gas phase or in aqueous phase, 1-chlorobutane was not transformed.

\section{Effect of Water Thermodynamic Activity on the Half-Life and Dehalogenase Activity}

The biofilter was packed with $100 \mathrm{mg}$ of lyophilized cells, maintained at $40^{\circ} \mathrm{C}$, and fed with $500 \mu \mathrm{mol} / \mathrm{min}$ of a

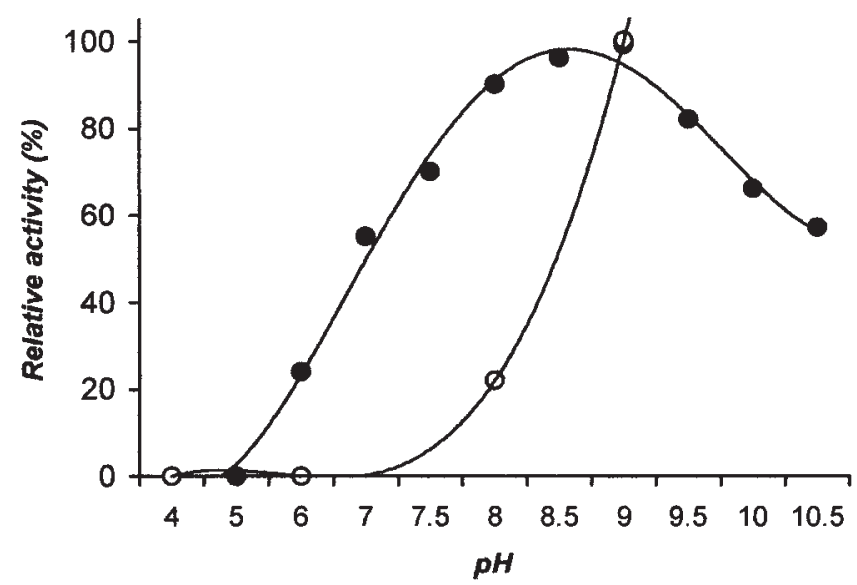

Figure 1. Effect of $\mathrm{pH}$ on relative dehalogenase activity of R. erythropoli cells in the gas phase $(O)$ and in the aqueous phase $(\bullet)$. Cells grown for $48 \mathrm{~h}$ on Sorkhoh's minimal medium supplemented by $2 \times 100 \mu \mathrm{l}$ of 1-chlorobutane were harvested and washed twice with $\mathrm{Tris} / \mathrm{HCl}$ buffer $(50 \mathrm{mM}, \mathrm{pH} 6.2,7.0,7.5,8.0,8.5$, or 9.0) and then incubated in Tris/ $\mathrm{HCl}$ buffer (50 mM, same $\mathrm{pH}$ as used for washing). Dehalogenation was measured as described in Materials and Methods and expressed relative to that observed at $\mathrm{pH} 9.0$. gaseous phase with a $a_{\mathrm{ClBut}}$ fixed at $0.06(8.1 \mu \mathrm{mol} / \mathrm{min})$. A critical $a_{\mathrm{w}}$ of 0.4 is necessary for the R. erythropolis cells to become active (Fig. 2), whereas the pure dehalogenase of $R$. erythropolis remains active even at lower $a_{\mathrm{w}}$ (Dravis et al., 2000). Similar results have been observed with yeast alcohol dehydrogenase (YADH) and whole baker's yeast cells (Yang and Russel, 1995; Maugard et al., 2001; Goubet et al., 2002). This is probably because of a different partitioning of water due to the presence of cellular material around the enzyme, thus leading to a greater need of water to reach sufficient "enzymatic flexibility."

When $a_{\mathrm{w}}$ increased the dehalogenase activity of dehydrated cells increased, in agreement with what has previously been reported for pure enzymes (Dravis et al., 2000). This behavior can partly be ascribed to the increase of mobility in the system and also to an increase of diffusion of substrates and products into cells. The increase in flexibility of the enzyme could also partly explain it. Graber et al. (2003) have shown that in a solid/gas system, increasing $a_{\mathrm{w}}$ has a positive effect on the flexibility of the catalyst. Moreover, water is one of the substrates involved in the reaction and, logically, increasing its activity also increases the rate of conversion and the amount of 1-butanol produced.

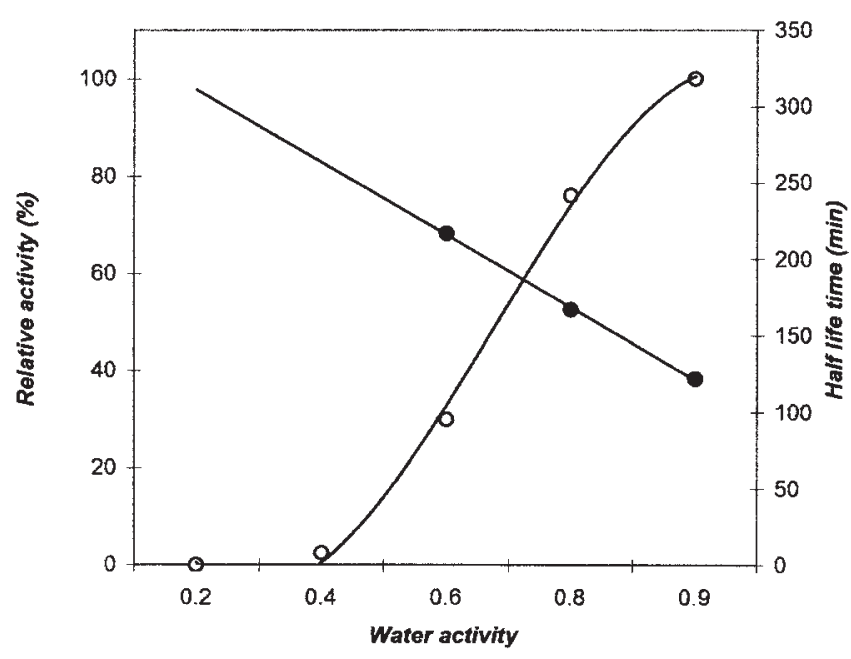

Figure 2. Effect of water activity on the half-life $(\bullet)$ and relative initial reaction rate $(O)$ of 1-butanol formation by lyophilized cells of R. erythropolis. The reaction was carried out at $40^{\circ} \mathrm{C}$ with $100 \mathrm{mg}$ of cells. The total flow into the biofilter was $500 \mu \mathrm{mol} / \mathrm{min}$. The 1 -chlorobutane activity was fixed at 0.06 . 
The maximal $a_{\mathrm{w}}$ for the conversion of 1-chlorobutane by lyophilized cells was 0.9 and in the range studied no decrease in activity was noticed when the water activity increased.

Conversely to the reaction rate, which increased with $a_{\mathrm{w}}$, the stability decreases. This decrease in stability is probably not due to thermal denaturation of the enzyme, since $40^{\circ} \mathrm{C}$ is its optimal temperature in the aqueous phase (Stafford, 1993) and since it has already been observed that enzymes used as catalysts in the gas phase are more stable than in the aqueous phase (Lamare et al., 2001; Cameron et al., 2002). However, it could be explained by an accumulation of $\mathrm{HCl}$ produced during dehalogenation. Indeed, $\mathrm{HCl}$ is a very hydrophilic molecule and probably diffuses very slowly through the membrane of cells in nonconventional media. The accumulation of $\mathrm{HCl}$ in the cells during the process decreases the $\mathrm{pH}$ of the microenvironment of the dehalogenase and consequently decreases the dehalogenase activity, as we previously showed (Fig. 1). This hypothesis is confirmed by the fact that the activity of the catalyst was restored by the addition of a volatile base such as triethylamine in the gaseous phase, or by the permeabilization of the cells by lysozyme (Fig. 3).

The permeabilization of cells means that $\mathrm{HCl}$ can diffuse more freely and accumulate more slowly in the cells. The decrease in $\mathrm{pH}$ and the inhibition of the dehalogenase also occurs later. The combined action of triethylamine and lysozyme confirms our assumptions. We added (at steady state) a nonreactive hydrophobic base (triethylamine), which is not a substrate of the dehalogenase. When the triethylamine is added (thermodynamic activity fixed at 0.05 , corresponding to $3.9 \mu \mathrm{mol} / \mathrm{min} . \mathrm{g}$ at $40^{\circ} \mathrm{C}$ ), the conversion of 1-chlorobutane is stimulated and the initial rate of 1-butanol formation increases. This stimulation is not only the result of the increase of the $\mathrm{pH}$ of the microenvironment of the enzyme, but also the result of the increase of the rate of release of the $\mathrm{Cl}^{-}$from the active site, thanks to the triethylamine action.

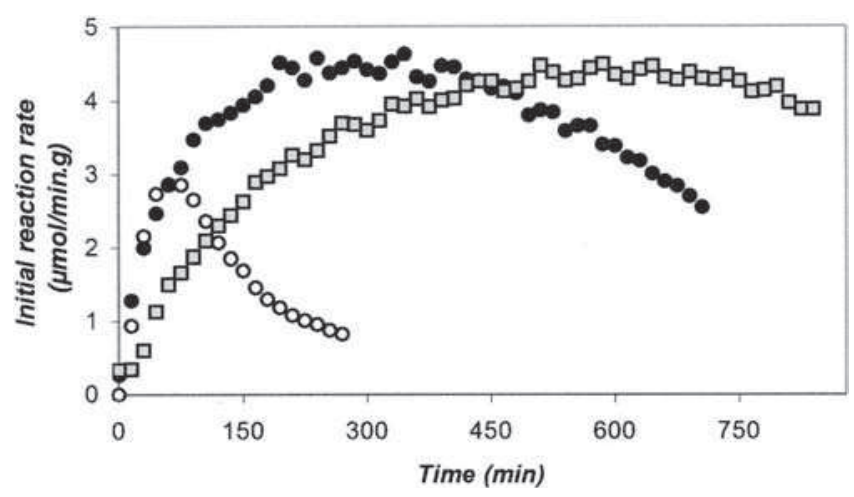

Figure 3. Continuous initial rate of the hydrolysis of 1-chlorobutane catalyzed by $R$. erythropolis as a function of reaction time. The reaction was carried out at $40^{\circ} \mathrm{C}$ with $100 \mathrm{mg}$ of dehydrated cells (O), cells treated with Lysozyme prior dehydration $(\bullet)$, or cells treated with lysozyme and with triethylamine in the gaseous phase $\left(a_{\mathrm{TEA}}=0.12(\square)\right)$. The total flow into the biofilter was $500 \mu \mathrm{mol} / \mathrm{min}$. The water activity and 1 -chlorobutane activities were fixed at 0.8 and 0.06 , respectively.

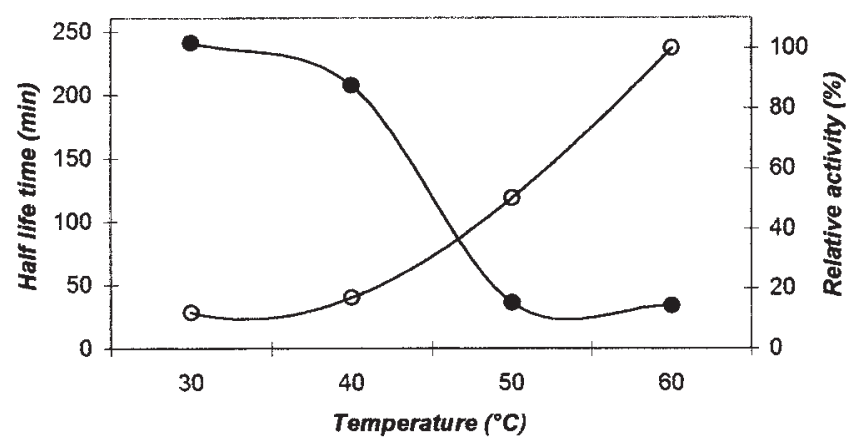

Figure 4. Effect of temperature on half-life (-) and relative initial reaction rate (O) of conversion of 1-chlorobutane by lyophilized $R$. erythropolis cells. The reaction was carried out with $100 \mathrm{mg}$ of cells. The total flow passing into the biofilter was $500 \mu \mathrm{mol} / \mathrm{min}$. The water activity and 1-chlorobutane activities were fixed at 0.8 and 0.06 , respectively. Rate obtained with a $30^{\circ} \mathrm{C}$ temperature was taken as reference.

Triethylamine plays the role of a volatile buffer that controls the local $\mathrm{pH}$ and the ionization state of the dehalogenase and prevents the inhibition of the dehalogenase. This phenomenon has been described for the free haloalkane dehalogenase in gas phase (Dravis et al., 2000). These two experiments confirmed that the dehalogenase was not denatured, but only inhibited by $\mathrm{HCl}$.

\section{Effect of Temperature on the Half-Life and Dehalogenase Activity}

The effect of temperature on the behavior of the catalyst was then studied. The biofilter was packed with $100 \mathrm{mg}$ of lyophilized $R$. erythropolis cells fed with $500 \mu \mathrm{mol} / \mathrm{min}$ of gaseous phase at an $a_{\mathrm{w}}$ fixed at 0.8 and an $a_{\mathrm{ClBut}}$ fixed at 0.06 . Reactions were carried out at temperatures ranging from $40-60^{\circ} \mathrm{C}$. As shown on Figure 4, the maximum initial reaction rate of 1-butanol formation increased with temperature but the half-life decreased. It was observed that the best compromise between the dehalogenase activity and the half-life of $R$. erythropolis cells was $40^{\circ} \mathrm{C}$. The exponential effect of temperature on activity of the catalyst is shown in

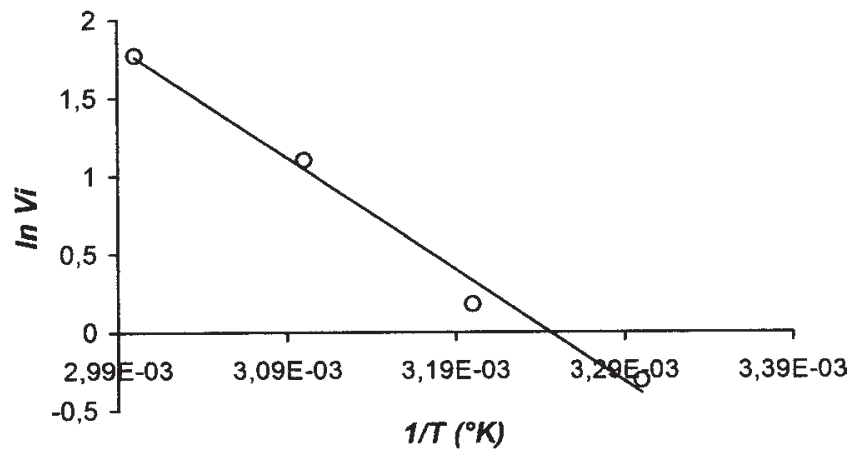

Figure 5. Effect of temperature on rate of formation of 1-butanol by lyophilized cells of $R$. erythropolis. The reaction was carried out with $100 \mathrm{mg}$ of cells. The total flow passing into the biofilter was $500 \mu \mathrm{mol} / \mathrm{min}$. The water activity and 1-chlorobutane activities were fixed at 0.8 and 0.06 , respectively. 
Figure 5. Since a linear relationship between the logarithm of the rate and the inverse of temperature was noticed, it can be deduced that there is no diffusional limitation and that the system is kinetically controlled. The activation energy of the reaction as determined by an Arrhenius plot was found to be $59.5 \mathrm{KJ} / \mathrm{mol}$, which is similar to values reported for haloalkane dehalogenases (Stafford, 1993).

\section{Dehalogenase Activity of Rhodococcus erythropolis Cells With Various Substrates}

The ability of $R$. erythropolis cells to dehalogenate a range of halogenated substrates in the aqueous phase and in the solid/gas phase is shown in Table IV. When harvested cells washed and resuspended in Tris/HCl buffer $(\mathrm{pH} 9.0)$, were exposed to 1-chlorobutane, 1-chloropentane, 1-chlorohexane, or 1-bromobutane, the same rate of degradation in a liquid system was observed (4.9 $\left.10^{-3} \mu \mathrm{mol} / \mathrm{min} . \mathrm{g}\right)$. We observed a slightly lower deha logenase activity using 1bromohexane as substrate, in agreement with the lower dehalogenase activity observed with the pure enzyme and this substrate (Stafford, 1993). No dehalogenase activity was observed with 1-chlorodecane and 2-chlorobutane. These results demonstrate that the dehalogenase of $R$. erythropolis has a preference, in the aqueous phase, for short chain compounds and for terminally substituted substrates. These results are in agreement with data published on resting cells or pure enzymes (Stafford, 1993; Curragh et al., 1994; Armfield et al., 1995).

In the solid/gas biofilter, the longer the carbon chain of the compound, the higher the initial rate of dehalogenation. This preference for $\mathrm{C}_{5}$ and $\mathrm{C}_{6}$ halogenated substrates was not observed in the aqueous phase. On the other hand, no

Table IV. Relative dehalogenase activity of $R$. erythropolis cells with various substrates.

\begin{tabular}{lccc}
\hline & A & B \\
\cline { 2 - 3 } Substrate & $\begin{array}{c}\text { Relative dehalogenase } \\
\text { activity of harvested cells } \\
\text { in aqueous phase (\%) }\end{array}$ & $\begin{array}{c}\text { Relative dehalogenase } \\
\text { activity of lypholized cells } \\
\text { in gaseous phase (\%) }\end{array}$ \\
\hline 1-chlorobutane & 100 & 100 \\
1-chloropentane & 101 & 186 \\
1-chlorohexane & 100 & 194 \\
1-chlorodecane & 0 & 0 \\
1-bromobutane & 98 & 98 \\
1-bromohexane & 87 & 301 \\
2-chlorobutane & 0 & 0 \\
\hline
\end{tabular}

Cells grown on minimal medium described by Sorkhoh et al. (1991) supplemented by $2 \times 100 \mu \mathrm{L}$ of 1 -chlorobutane were harvested and washed twice with Tris/ $\mathrm{HCl}$ buffer $(50 \mathrm{mM}, \mathrm{pH} 9.0)$ and then either incubated in Tris/ $\mathrm{HCl}$ buffer $(50 \mathrm{mM}, \mathrm{pH} 9.0)$ with halogenated substrates (A) or lyophilized. In the solid-gas biofilter (B), the reaction was carried out with $100 \mathrm{mg}$ of lyophilized cells. The total flow in the biofilter was $500 \mu \mathrm{mol} / \mathrm{min}$. The water activity and halogenated compound activities were fixed at 8.0 and 0.06 , respectively. activity was found with 1-chlorodecane and 2-chlorobutane, as was the case in the aqueous phase.

\section{CONCLUSION}

For the first time, this study has shown the ability of whole $R$. erythropolis cells to dehalogenate a range of chlorinated and brominated substrates in the gas phase at significant rates compared to those observed in the aqueous phase. The influence of parameters such as water thermodynamic activity, temperature, and total flow into the solid/gas biofilter were studied. A decrease in the stability of the solid/gas biofilter versus time was observed. This was related to the accumulation of $\mathrm{HCl}$ in the cells, lowering local $\mathrm{pH}$, and could be limited by the addition of a volatile base or by the permeabilization of the cells.

Studies are currently in progress to determine if further degradation of the alcohols and also a multistep conversion can be obtained with the same microorganism in a solid/ gas biofilter.

\section{References}

Armfield SJ, Sallis P, Baker PB, Bull AT, Hardman DJ. 1995. Dehalogenation of haloalkanes by Rhodococcus erythropolis Y2. Biodegradation 6:237-246.

Belkin S. 1992. Biodegradation of haloalkanes. Biodegradation 3:299-313.

Cameron PA, Davidson BH, Frymier PD, Barton JW. 2002. Direct transesterification of gases by "dry" immobilized lipase. Biotechnol Bioeng 78:251-256.

Cox HHJ, Deshusses MA. 1998. Biological waste air treatment in biotrickling filters. Curr Opin Biotechnol 9:256-262.

Curragh H, Flynn O, Larkin MJ, Stafford TM, Hamilton JTG, Harper DB. 1994. Haloalkane degradation and assimilation by Rhodococcus rhodochrous NCIMB 13064. Microbiology 140:1433-1442.

Dravis BC, Lejeune KE, Heltro AD, Russel AJ. 2000. Enzymatic dehalogenation of gas phase substrates with haloalkane dehalogenase. Biotechnol Bioeng 69:235-241.

Goubet I, Maugard T, Lamare S, Legoy MD. 2002. Role of water activity and temperature on activity and stability of dried whole cells of Saccharomyces cerevisiae in a continuous solid gas bioreactor. Enzyme Microb Technol 31:425-430.

Graber M, Bousquet-Dubouch MP, Sousa N, Lamare S, Legoy MD. 2003. Water plays a different role on activation thermodynamic parameters of alcoholisis reaction catalyzed by lipase in gaseous and organic media. Biochim Biophys Acta 1645:56-62.

Halling PJ. 2000. Biocatalysis in low-water media: understanding effects of reaction conditions. Curr Opin Chem Biol 4:74-80.

Jorio H, Heitz M. 1999. Traitement de l'air par biofiltration. Can J Civ Eng 26:402-424.

Keith LH, Teilliard WA. 1979. Priority pollutants. I. A perspective view. Environ Sci Technol 13:416-423.

Lamare S, Legoy MD. 1993. Biocatalysis in the gas phase. Trends Biotechnol 11:413-418.

Lamare S, Legoy MD. 1995. Solid/gas biocatalysis how to fully define the system? Biotechnol Tech 9:127-132.

Lamare S, Caillaud B, Roule K, Goubet I, Legoy MD. 2001. Production of natural esters at the pre-industrial scale by solid/gas biocatalysis. Biocat Biotrans 19:361-377.

Maugard T, Lamare S, Legoy MD. 2001. Gas phase biotransformation reaction catalyzed by baker's yeast. Biotechnol Bioeng 73:164-168. 
Menig H, Krill H. 1997. Jäschke kosten und Effizienz Biologisher Verfahren im Vergleich zum Anderen Ablufttreinigungssystemen. In: Prins WL, Van Ham J, editors. Proceeding of the biological waste gas cleaning international symposium, Maastricht, the Netherlands, 28-29 April 1997.

Poelarends GJ, Kulakov LA, Larkin MJ, Van Hylckama Vlieg JET, Janssen D. 2000. Roles of horizontal genes transfer and gene integration in evolution of 1,3-dichloropropene- and 1,2-dibromoethane-degradative pathways. J Bacteriol 182:2191-2199.

Sorkhoh NA, Ghannoum MA, Ibrahim AS, Stretton RJ, Radwan SS. 1991. Growth of Candida albicans in the presence of hydrocarbons: a correlation between sterol concentration and hydrocarbon uptake. Appl Microbiol Biotechnol 34:509-512.

Stafford TM. 1993. The microbiol degradation of chloroalkanes. PhD Thesis. Queens University of Belfast, Belfast, United Kingdom.

US EPA (United States Environmental Protection Agency). 1990. CAAA (Clean Air Act Amendments). http://tnwww.rtpnc.epa.gov/.

Yang F, Russel AJ. 1995. The role of hydration in enzyme activity and stability. 2. Alcohol dehydrogenase activity and stability in a continuous gas phase reactor. Biotechnol Bioeng 49:709-716.

Zaks A, Klibanov AM. 1985. Enzyme-catalyzed processes in organic solvents. Proc Natl Acad Sci USA 82:3192-3196. 